\title{
RESISTENSI TERHADAP KOLONIALISME DALAM NOVEL GERHANA MERAH KAJIAN POSTKOLONIAL
}

\author{
Danang Bagus Juliantono \\ (Program Studi Pendidikan Bahasa Indonesi , Fakultas Keguruan dan Ilmu Pendidikan, \\ Universitas Pgri Adi Buana Surabaya) \\ monkeydbagus@gmail.com \\ Taufik Nurhadi \\ (Program Studi Pendidikan Bahasa Indonesi , Fakultas Keguruan dan Ilmu Pendidikan, \\ Universitas Pgri Adi Buana Surabaya) \\ taufiknurhadi70@gmail.com
}

\begin{abstract}
This study aims to describe the form of resistance to colonialism in the Red Eclipse novel . The theory used in this study is postcolonialism to see the forms of resistance contained in the novel. In postcolonial theory there are elements of resistance, namely passive resistance and radical resistance, namely hybridity, ambivalence, decolonization and anticolonialism carried out by characters in novels who experience colonialism. The method used in this study, namely a qualitative approach. Data from this study are in the form of words, sentences and paragraphs that describe colonialism in the novel. The data source in this study is the Red Eclipse novel written by Muhammad Sholihin. Data collection in this study uses documentation techniques. The step of analyzing by reading, interpreting and concluding. The results of this study were postcolonial not as something that came after colonialism and signaled the death of colonialism, but more loosely regarded as a resistance to colonial domination, and in the Red Eclipse novel there were two forms of resistance to colonialism namely passive resistance and radical resistance. Passive resistance is shown by the natives with the manifestation of themselves to refuse, namely a resistance that uses other means to maintain cultural identity and ownership. While Radical Resistance acts like an army or combat army, the struggle to liberate the nation from colonialism. organized movement plans, which are carried out by attacking directly.
\end{abstract}

Keywords : Resistences, Postcolonialism

\section{PENDAHULUAN}

Melalui karya sastra, seorang pengarang menyampaikan pandanganya tentang kehidupan yang ada disekitarnya. sebab itu, mengapresiasi karya sastra adalah suatu usaha menemukan nilai-nilai kehidupan yang tercermin dalam karya sastra. Banyak nilai-nilai kehidupan yang bisa ditemukan dalam karya sastra tersebut, sastra sebagai hasil pengolahan jiwa pengarangnya dihasilkan melalui suatu proses perenungan yang panjang mengenai hakikat hidup dan kehidupan. Sastra ditulis dengan penuh penghayatan dan sentuhan jiwa yang dikemas dalam imajinasi yang dalam tentang kehidupan. Berbicara tentang Karya satra, karya sastra dapat digolongkan menjadi tiga macam, yaitu puisi, drama, dan prosa. Berbicara tentang prosa, Prosa adalah karya sastra yang berbentuk tulisan bebas. Bersifat bebas artinya prosa tidak terikat dengan aturan-aturan tulisan seperti rima, diksi, irama, dan lain sebagainya. Berdasarkan jamannya, prosa dibedakan menjadi dua jenis, yaitu prosa lama dan prosa baru. Berikut ini adalah bentuk, ciri 
dan contoh dari prosa lama dan prosa baru. Prosa baru adalah bentuk karya sastra yang telah dipengaruhi oleh kebudayaan barat. Bentuk prosa ini muncul karena prosa lama dianggap tidak moderen dan ketinggalan jaman. Bentuk-bentuk prosa baru antara lain: roman, cerpen dan novel, Novel adalah cerita yang panjang tentang kehidupan, sifatnya bias fiktif atau no-fiktif. Sebagai satu bentuk kegiatan ilmiah, penelitian sastra memerlukan landasan kerja yang berupa teori, teori sebagai perenungan yang mendalam, mensistem, dan terstruktur terhadap gejala-gejala alam berfungsi sebagai pengarah dalam kegiatan penelitian. Sehingga dalam penelitian kali ini saya akan menggunakan teori poskolonial sebagai pengarah dalam kegiatan penelitian ini. Pada dasarnya postkolonial umumnya didefinisikan sebagai teori yang lahir sesudah kebanyakan negara-negara terjajah yang memperoleh kemerdekaannya. Poskolonialisme merupakan bentuk penyadaran dan kritik atas kolonialisme. Poskolonialisme menggabungkan berbagai disiplin keilmuan mulai dari filsafat, cultural studies, politik, bahasa sastra, ilmu sosial, sosiologi, dan feminisme. Postkolonial bukan berarti setelah kemerdekaan, tetapi poskolonial dimulai ketika kontak pertama kali penjajah dengan masyarakat pribumi.

Salah satu karya sastra yang menyajikan resistensi pribumi terhadap penjajahan adalah novel Gerhana Merah karya Muhammad Sholihin, sehingga novel ini dipilih menjadi objek materi penelitian ini. yang mengambil setting masa penjajahan kolonial Belanda. Ketika tubuh bangsa ini dicabik-cabik oleh kolonialisme. Orang orang yang hidup diatasnya; mati rasa oleh penderitaan dan penuh duka akibat dieksploitasi oleh bangsa sendiri terlebih, apalagi oleh kolonialisme belanda. Akhirnya sebuah masa tiba, ketika revolusi rusia yang digerakan oleh kaum buruh membuka mata dunia, terutama bangsa bangsa terjajah. Bagaikan tersengat aliran listrik; sebagian rakyat indonesia yang berkesadaran ikut menggerakan bangsa ini untuk memperjuangkan nasibnya dan keluar dari penindasan kolonialisme belanda sehingga diduga di dalam novel tersebut terungkap adanya wacana kolonial.

Dari uraian diatas maka akan ditarik rumusan masalah untuk penelitian ini untuk mendeskripsikan Resistensi Terhadap Kolonialisme dalam novel Gerhana Merah dengan Kajian Postkolonial.

\section{METODE PENELITIAN}

Kajian ini menggunakan pendekatan kualitatif, karna penelitan ini membicarakan fenomenafenomena yang ada didalam novel Gerhana Merah karya Muhammad Sholihin.

Sumber data dalam penelitian berupa novel Gerhana Merah karya Muhammad Sholihin yang diterbitkan oleh penerbit Gorong pada tahun 2018 dengan tebal emboh halaman.

Data kajian ini adalah teks yang mengandung resistensi terhadap kolonialisme dalam kajian postkolonial.Teknik pengumpulan data dalam kajian ini menggunakan metode dokumentasi. disamping dengan cara ini penelitian bisa lebih mudah karena data yang teliti berupa penggalan teks sastra tentang resistensi atau perlawanan penduduk terhadap penjenjajahan belanda dan tuan tanah. berupa aspek Sosial Budaya, Ekonomi, Politik dan tindakan kekerasan secara pasif dan radikal. 
Analisis data dalam penelitian ini dengan menggunakan pendekatan kualitatif maka data yang dihasilkan berupa kata-kata atau paragraf yang juga disebut dengan data deskriptif, karena penelitian ini berusaha menggambarkan atau menginterpretasikan dengan apa adanya.

\section{HASIL DAN PEMBAHASAN}

Resistensi Pasif Terhadap Kolonialisme dalam Novel Gerhana Merah Kajian Postkolonial

Hasil penelitian ini mendeskripsikan tentang bentuk perlawanan subaltern atau pribumi terhadap kolonialisme yang diterapkan para tuan tanah dan belanda untuk menindas dan mengeksploitasi para pribumi. Dan dari hasil penelitian ini menunjukan Bahwa para tokoh melakukan resistensi yang bersifat pasif yang disebut resistensi bersifat pasif sebagai perwujudan dirinya untuk menolak, yakni sebuah resistensi atau perlawanan yang menggunakan cara lain dengan pemertahanan identitas dan kepemilikan budaya yang terdapat dalam Novel Gerhana Merah karya Muhammad Sholihin.

\section{(1) Resistensi Pasif Hibriditas}

\section{dalam Novel Gerhana Merah}

Bentuk-bentuk Hibriditas di lingkungan kolonial dapat berfungsi sebagai sarana untuk mendefinisikan medan baru yang bebas dari ortodoksi rezim kolonial, ortodoksi rezim kolonial adalah 'sebuah ajaran yang benar' terkadang hal ini diartikan sebagai ajaran yang lama yang diterapkan pihak penjajah. maupun identitas-identitas nasionalis bayangan yang harus menggantikannya.
Dalam Novel Gerhana Merah terdapat bentuk-bentuk Hibriditas Budaya yang dilakukan pribumi, yaitu Pada aspek kebudayaan kepada budaya indonesia pada saat penjajahan dan budaya asing yang mereduksi khasanah budaya lokal yang dimaksud mereduksi adalah mengurangi budaya bangsa seperti mempengaruhi karakter dan perilaku masyarakat yang hanya diam dan terpaku atas penjajahan yang dilakukan oleh tuan tanah dan belanda, Hal ini dijelaskan oleh tokoh yang bernama Mas Cokro dan Seperti yang terdapat di dalam novel, diceritakan tokoh mas cokro melakukan bentuk hibriditas kultural untuk mengurangi budaya bangsa seperti mempengaruhi karakter dan perilaku masyarakat Adapun kutipanya dapat dicermati di bawah ini:

"Mas Cokro Fokus menumbuhkan kesadaran kelas penduduk Taratak Siguman. Dengan nada suara yang kharismatik dibarengi mimik yang ekspresif, Mas Cokro meyakinkan bahwa waktu untuk bertindak sudah dekat. Keberanian harus ditumbuhkan. Tekad harus dibulatkan. Rasa benci saatnya dilipatgandakan." (Halaman: 184)

Dari cuplikan diatas menunjukan bahwa tokoh yang bernama Mas Cokro melakukan bentuk Hibriditas budaya untuk mengurangi budaya bangsa dengan cara mengagitasi penduduk, mengagitasi adalah menghasut orang banyak untuk mengadakan pemberontakan, serta mempengaruhi karakter dan perilaku masyarakat untuk memberanikan diri melawan setiap bentuk ketidakadilan yang dilakukan oleh Tuan Tanah dan belanda dengan menggunakan paham 
marxisme, dalam ilmu politik marxisme adalah ideologi negara resmi uni soviet, tujuan paham marxisme adalah mengembangkan negara kapitalis menjadi negara sosialis. Negara kapitalis merupakan negara dengan sistem ekonomi di mana perdagangan, industri dan alatalat produksi dikendalikan oleh pemilik swasta atau pemilik modal contohnya pemerintahan. dengan tujuan memperoleh keuntungan yang besar. Terus dikembangkan menjadi negara sosialis yang biasa disebut negara buruh merujuk kepada negara manapun yang secara konstitusi atau undang-undang dasar didedikasikan untuk pendirian sosisalisme yang ditandai dengan kepemilikan sosial.

\section{(2) Resistensi Pasif Ambivalensi dalam Novel Gerhana Merah}

Dalam Novel Gerhana Merah terdapat bentuk-bentuk ambivalensi yang dilakukan pribumi yang dimaksud dengan ambivalensi adalah konsep yang berupaya untuk menjelaskan keragaman pilihanpilihan yang ditawarkan pada subjeksubjek kolonial bagi pembentukan identitas. Ambivalensi mengacu pada hakikat yang tidak stabil, berlawanan, dan tidak identik dari wacana kolonial. Konsep Ambivalensi diturunkan dari ranah psikoanalisis yang digunakan untuk menggambarkan fluktuasi yang terusmenerus antara menginginkan sesuatu hal dan menginginkan kebalikannya.

Dalam Novel Gerhana Merah terdapat bentuk-bentuk Sikap ambivalen yang dilakukan pribumi yaitu menghasilkan benih-benih kehancurannya sendiri. Ini kontroversial karena menyiratkan bahwa hubungan kolonial akan terganggu, meskipun ada perlawanan atau pemberontakan pada bagian dari terjajah. Adapun kutipanya dapat dicermati di bawah ini:

"Bukan aku tidak setuju melawan belanda, tapi menjadikan para tuan tanah, para damang sebagai sasaran amuk; sungguh aku berkeberatan." (Halaman: 206)

Dari Kutipan diatas menunjukan bahwa Tokoh Mahesa yang menolak melawan belanda dikarenakan para tuan tanah juga akan ikut dibunuh, adalah sikap Ambivalensi. Ambivalensi mengacu pada hakikat yang tidak stabil, berlawanan, dan tidak identik atau tidak sama dari wacana kolonial. Kutipan di atas sejalan dengan Ambivalensi yang digunakan untuk menggambarkan fluktuasi, fluktuasi adalah ketidak tetapan atau guncangan, fluktuasi timbul dari prinsip ketidakpastian. antara menginginkan sesuatu hal dan menginginkan kebalikannya. Padahal Mahesa adalah otak dari pembantaian para tuan tanah tetapi seiring berjalanya waktu mahesa sadar bahwa ia hanya mendapatkan penyesalan akan semua itu meskipun mahesa ingin sekali melenyapkan kompeni belanda tanpa membunuh tuan tanah.

Resistensi Radikal Terhadap Kolonialisme dalam Novel Gerhana Merah Kajian Postkolonial

Hasil penelitian ini mendeskripsikan tentang bentuk perlawanan subaltern atau pribumi terhadap kolonialisme yang diterapkan para tuan tanah dan belanda untuk menindas dan mengeksploitasi para pribumi. Dan dari hasil penelitian ini menunjukan Bahwa para tokoh melakukan resistensi yang bersifat radikal yang disebut resistensi bersifat radikal yaitu dicirikan oleh adanya rencanarencana pergerakan yang terorganisasi, yang dilakukan dengan 
menyerang secara langsung melalui peperangan atau dengan memproduksi teks atau bacaan.

\section{(1) Resistensi Radikal Dekolonisasi dalam Novel Gerhana Merah}

Dalam Novel Gerhana Merah terdapat bentuk-bentuk Dekolonisasi yang dilakukan pribumi yang dimaksud dengan Dekolonisasi adalah proses mengungkapkan dan membongkar kekuasaan kolonialis dalam segala bentuknya. Ini termasuk pembongkaran aspek tersembunyi dari kekuatan-kekuatan kelembagaan dan budaya yang telah mempertahankan kekuatan kolonialis dan yang tetap bahkan setelah kemerdekaan politik tercapai. Awalnya, di banyak tempat di dunia terjajah, proses perlawanan dilakukan dalam hal atau lembaga yang berasal dari budaya kolonial itu sendiri.

\section{(a) Dekolonisasi Penolakan}

Bentuk Resistensi radikal yaitu penolakan dalam Novel Gerhana Merah tampak pada Tokoh Nadhim yang hanya bisa menuruti perintah majikan, ia tak punya hak untuk melawan apalagi menegakan martabat di depan majikanya, sejalan dengan konsep. Wujud perlawanan atau Resistensi Pertama adalah desakan kuat akan hak untuk melihat sejarah masyarakat secara menyeluruh,koheren dan terpadu, berawal dari kesadaran Nadhim akan haknya telah direnggut oleh majikan ia bagaikan seorang budak yang jatuh pada tangan tuan yang salah, martabatnya dibeli dan harkatnya dihancurkan Perasaan-perasaan dan pengalaman itu membuat diri Nadhim semakin sadar bahwa ia dan budakbudak lain yang diperlakukan tidak adil, oleh karena itu Nadhim merasa dendam mencurahkan perkataanya kepada Demang Doporo. Adapun kutipanya dapat dicermati di bawah ini:

"Nadhim menggerutu dalam hati, Daporo! Uang dan kekuasaan yang kau miliki akan membunuh dirimu dengan khidmatnya. Kelak, suatu saat kalian pemilik kekuasaan dan bermahkotahkan uang akan menciumi telapak kaum seperti aku ini. Tak lama lagi aku dan mereka, serpihan serpihan yang terbuang akan bersatu dan menuntut balas, ingatlah ledakan emosi ini tak lama lagi. Tunggulah!" (Halaman: 49)

Dari kutipan diatas memaparkan bahwa Nadhim mencoba untuk melawan para tuan tanah. Dengan ancaman akan menuntut balas atas perlakuan para tuan tanah kepada budak-budak seperti dia, yang akan memberontak atas praktek kolonial seperti ini dan menolak tegas diperintah oleh tuan tanah.Bentuk resistensi penolakan yang dilakukan Nadhim yaitu dengan cara mengancam para tuan tanah dan membuat gerakan perlawanan serta tidak akan lagi bekerja dan melayani para tuan tanah.

\section{(b) Dekolonisasi Pemahaman}

Dalam Novel Gerhana Merah terdapat bentuk-bentuk Pemahaman yang dilakukan pribumi adalah ide bahwa resistensi bukan sekadar reaksi terhadap imperialisme, imperialisme adalah sebuah kebijakan di mana sebuah negara besar dapat memegang kendali atau pemerintahan atas daerah lain agar negara itu bisa dipelihara atau berkembang. tetapi merupakan cara alternatif untuk memahami sejarah manusia.

"Pada awalnya, semuanya harus dihancurkan semua hukum yang telah membangun peradaban 
kita, harus dibakar dan dihancurkan. Hukum itu hanya menjadi topeng menyembunyikan kebusukan penguasa dan elite-elite desa yang terus menghisap keringat petani, ini harus dilakukan sebelum kita membawa kebaikan pada dunia, "sunarti berujar, dengan kalimat menghasut tapi bernada persuasif" (Halaman: 67)

Dari kutipan diatas menunjukan bahwa Sunarti menolak hukum yang diciptakan para penguasa dan elite-elite desa, karena hukum yang diterapkan tidak mensejahterakan pribumi, sejalan dengan konsep. Wujud perlawanan atau Resistensi Kedua adalah ide bahwa resistensi bukan sekadar reaksi terhadap imperialisme, Jadi intinya resistensi bukan hanya sekedar dimana sebuah negara besar dapat memegang kendali tapi masyarakat harus peka akan terjadinya hal itu seperti menolak kolonialisme ataupun imperialisme. merupakan cara alternatif untuk memahami sejarah manusia. Ide Sunarti adalah menolak hukum yang sudah di terapkan pihak belanda dan para tuan tanah, sejarah dimana Hukum yang bersifat melindungi rakyat di ganti dengan hukum dibuat sebagai pelindung dari ancaman rakyat lapar dan geram dalam kemiskinan yang sengaja diciptakan para penguasa.

\section{(c) Dekolonisasi Pembebasan}

Dalam Novel Gerhana Merah terdapat bentuk-bentuk Pembebasan yang dilakukan pribumi adalah suatu tarikan nyata untuk menjauh dari nasionalisme separatis adalah kurangnya perasaan kekuatan politis dan ekonomi suatu kelompok ke arah suatu pandangan yang lebih integratif dari komunitas manusia dan pembebasan manusia. Integratif adalah penyatuan berbagai aspek ke dalam suatu keutuhan yang padu.

Berbicara tentang kebebasan dan sumber penghidupan para penduduk yang terbuang seperti Nadhim dan para budak-budak yang telah melarikan diri dari jorong karena tempat itu sudah dikuasai oleh para penguasa dan elite-elite, mereka sekarang berada pada Taratak siguman yang merupakan lembah yang bergaung tapi wujudnya pun tak dapat diendus oleh penduduk kampung lain maupun belanda, berikut adalah kutipan yang mendeskripsikan uraian tersebut.

"Penduduknya yang berjumlah lima puluh orang, jauh sesungguhnya disebut sebagai sebuah kampung, mereka merdeka mengekspresikan hidup tanpa aturan hipokritdari hukum buatan manusia, yang tak pernah adil bagi orang-orang miskin, apalagi lemah dan terpinggirkan." (Halaman: 62)

Dari kutipan diatas memaparkan bentuk Dikolonisasi tentang pembebasan yaitu kebebasan para Pribumi buangan yang melarikan diri dari jorong tempat praktek kolonial para tuan tanah. Sejalan dengan konsep. Wujud perlawanan atau resistensi Ketiga adalah suatu tarikan nyata untuk menjauh dari nasionalisme separatis ke arah suatu pandangan yang lebih integratif dari komunitas manusia dan pembebasan manusia. Pada dasarnya masyarakat pribumi yang telah terbuang dan melarikan diri dari jorong merupakan bentuk resistensi pembebasan karena suatu tarikann nyata untuk menjauh dari nasionalisme separatis yang tidak pernah adil bagi orang miskin lemah dan terpinggirkan.

\section{(2) Resistensi Radikal Mimikri dalam Novel Gerhana Merah}


Dalam Novel Gerhana Merah terdapat bentuk-bentuk mimikri yang dilakukan pribumi yang dimaksud dengan mimikri adalah reproduksi belang-belang subjektifitas Eropa di lingkungan kolonial yang sudah tidak murni, yang tergeser dari asal-usulnya dan terkonfigurasi ulang dalam cahaya sensibilitas dan kegelisahan khusus kolonialisme.

"Pada kondisi tertekan dan tertindas, tak bisa melakkan apapun; Rakyat Jelata lebih memilih peran sebagai penabur satire. Mengejek, menghina, mempergunjing di warung. Hanya sebatas itu belum mengerucut menjadi keberanian memanggul senjata." (Halaman: 243)

$\begin{array}{rrr}\text { Dari } & \text { Kutipan } & \text { diatas } \\ \text { menunjukan } & \text { bahwa } & \text { Rakyat }\end{array}$ melakukan Peniruan Perilaku, yang Yang disebut belang belang subjektifitas, belang belang subjektifitas adalah bentuk tidak formal fakta yang ada di dalam pikiran manusia sebagai persepsi, keyakinan dan perasaan. Mimikri sebenarnya sebagai sebuah tindakan subjek kolonial yang memuja atau mengagung-agungkan budaya kolonial, yang dimaksud mengagungagungkan budaya kolonial adalah berfikir kalau budaya kolonial lebih baik dari pada budaya lokal maka dari itu pribumi melakukan bentuk perlawanan Peniruan. Peniruan Perilaku yakni sebuah bentuk resistensi yang menggunakan cara lain dengan pemertahanan identitas dan kepemilikan budaya. Pada kutipan diatas menyebutkan rakyat jelata lebih memlih menjadi penabur satire. Yang disebut sebagai penabur satire adalah gaya bahasa untuk menyatakan sindiran terhadap suatu keadaan. Mengejek, menghina adalah bentuk mimikri atau peniruan terhadap kompeni yang suka menghina pribumi. Dikarenakan pribumi hanya bisa melakukan perlawanan hanya sebatas itu mempergunjing dan mengejek belum mengkrucut atau belum berani untuk memegang senjata.

\section{(3) Resistensi Radikal Antikolonial dalam Novel Gerhana Merah}

Dalam Novel Gerhana Merah terdapat bentuk-bentuk Antikolonial yang dilakukan pribumi adalah menandakan titik di mana berbagai bentuk oposisi menjadi diartikulasikan sebagai perlawanan terhadap operasi kolonialisme di lembaga-lembaga politik, ekonomi dan budaya Antikolonialisme adalah perjuangan politik dari rakyat terhadap ideologi dan praktek kolonialisme. Ini menekankan perlunya untuk menolak kekuasaan kolonial dan mengembalikan kontrol lokal. Paradoksnya, gerakan antikolonialis sering menyatakan diri dalam perampasan dan subversi, subversi adalah upaya merobohkan struktur kekuasaan termasuk negara. Bentuk dipinjam dari lembaga penjajah dan kembali pada mereka. Dengan demikian perjuangan sering diartikulasikan dalam hal wacana anti-kolonial 'nasionalisme' di mana bentuk Eropa negara-bangsa modern yang diambil alih dan digunakan sebagai tanda perlawanan.

"Topik pembicaraan pun berubah Tentang pergerakan melawan kolonialisme, tentang konflik ketidaksamaan pandangan juga tentang pembantaian massal, melawan tuan tanah." (Halaman: 202)

Pada kutipan diatas memaparkan bentuk Kelompok Antikolonial merupakan perlawanan masyarakat terjajah terhadap kekuasaan kolonial. Resistensi radikal 
dicirikan oleh adanya rencanarencana pergerakan yang terorganisasi, yang dilakukan dengan menyerang secara langsung melalui peperangan atau dengan memproduksi teks atau bacaan. Yang sudah di sebutkan di atas bahwa Resistensi radikal dicirikan dengan adanya rencana-rencana pergerakan yang terorganisasi ).

Tambahan dengan ini sesuai dengan penjelasan mengenai Kelompok Antikolonial di atas merupakan bentuk Resistensi radikal merupakan perlawanan masyarakat terjajah terhadap kekuasaan kolonial. Resistensi radikal dicirikan oleh adanya rencana-rencana pergerakan yang terorganisasi, yang dilakukan dengan menyerang secara langsung melalui peperangan atau dengan memproduksi teks atau bacaan, dari kutipan di atas menunjukan Perlawanan masyarakat terjajah terhadap kolonialisme.

\section{SIMPULAN}

Penelitian ini mengkaji bentuk kolonialisme dalam Novel Gerhana Merah Karya Muhammad Sholihin dengan menggunakan teori postkolonialisme. Poskolonialisme merupakan teori untuk menganalisis segalah bentuk penjajahan yang terjadi dari dahulu sampai sekarang. Poskolonialisme memiliki beberapa unsur, salah satunya adalah bentuk Resistensi, perlawanan sikap atau tindakan yang dibentuk untuk membebaskan rakyat dari penindasanya, Resistensi tidak sepenuhnya berbentuk penolakan atau pembalikan secara mutlak karena adanya representasi penjajah dalam diri terjajah. Rumusan kedua ini mencerminkan bahwa dalam melakukan perlawanan/resistensi ada dua bentuk resistensi yang dilakukan kaum terjajah, yakni perlawanan yang prontal (radikal) dan pasif, seperti melakukan peniruan (mimikri) terhadap tindakan penguasa.

Hasil dari penelitian ini dapat ditarik kesimpulan bahwa Poskolonial bukan sebagai sesuatu yang datang setelah kolonialisme dan menandakan kematian kolonialisme ini, tetapi secara lebih longgar dianggap sebagai suatu perlawanan terhadap dominasi kolonialisme dan warisan warisan kolonialisme. Dari hasil data yang didapat dari Novel Gerhana Merah Karya Muhammad Sholihin, bahwa pribumi melakukan dua bentuk resistensi terhadap penjajahan yaitu resistensi pasif dan resistensi radikal. Resistensi pasif ditunjukan pribumi dengan perwujudan dirinya untuk menolak, yakni sebuah resistensi yang menggunakan cara lain dengan pemertahanan identitas dan kepemilikan budaya. Sedangkan Resistensi Radikal berperan ibarat sebagai pasukan/tentara tempur, perjuangan membebaskan bangsa dari penjajahan. rencana-rencana pergerakan yang terorganisasi, yang dilakukan dengan menyerang secara langsung.

\section{DAFTAR PUSTAKA}

Ghandi, Leela. 2014. Teori Poskolonial Upaya Meruntuhkan Hegemoni Barat. Yogyakarta : Qalam

Yasa, Nyoman, I. 2014. Poskolonial Teori Dan Penerapanya Dalam Sastra Indonesia Mutakhir. Yogyakarta : Graha Ilmu

Mashlihatin, Anis. 2013. Teori pascakolonialisme Homi k.bhaba: ontologi dan epistemologinya diambil dari: https://poskolonialisme.wordp 
ress.com, diunduh 25 Agustus 2018

Sholihin, Muhammad. 2018. Gerhana Merah. Yogyakarta: Diva Press

Rokhmansyah, Alfian.I.2014.Studi Dan Pengkajian

Sastra,Perkenalan Awal Terhadap Ilmu Sastra.Yogyakarta : Graha Ilmu

Jabrohim.VII.2015.Teori Penelitian Sastra.Yogyakarta : Pustaka Pelajar

Emzir, dan, Rohman, Saifur. 2015, Teori Pengajaran Sastra. Jilid I. Jakarta : Rajagrafindo Persada

Loomba, Ania, I.2016. Kolonialisme/poskolonialisme. Yogyakarta: Pustaka Promethea

Ratna,Nyoman Kutha, X. 2015. Teori Metode Dan Teknik Penelitian Sastra. Yogyakarta: Pustaka Pelajar

Anwar, M, Shoim, V.2017. Sastra Lama.Lamongan: Pustaka Ilalang

Ashcroft, Bill dkk. 2007. Postcolonial Studies, The key Concepts Second Edition : Penulis buku referensi di atas adalah Bill Ashcroft, Gareth Griffiths dan Helen Tiffin Sutejo dan Kasnadi. 2016, Apresiasi Prosa. Jilid I. Yogyakarta : Terakata

Agustiningsih, Ika. Hibriditas dalam Novel Burung-Burung Manyar karya YB Mangunwijaya (Kajian Pascakolonial). Skripsi. Universitas Muhammadiyah Malang 